\title{
Hegemonisk maskulinitet - genbesøgt
}

Af Helle Bjerg

Hvordan kan begreber om affekt og intensitet inspireve og udfordre analyser af subjektivering og intersektionalitet? I Sørens evindringer om livet $i$ skolen kan et analytisk fokus på affekt og intensitet bidrage med analyser af, bvordan det at blive til som passende hvid dreng $i$ skolegården ikke alene er noget, der gøres, men også noget, der markes på langs og på tvars af de subjektpositioner, som tilbydes $i$ skolelivet.

\section{C6}

ballademager; stille pige; god elev; fra landet. "Jeg var ikke en af dem, der ..." rakte hånden op; fik gode karakterer; turde lave ballade; var populær blandt drengene. "Der var dem der..." lugtede; gik i brugsen; var fra byen. "Der var..." fessortyperne, klumpedumperne og de mindre kloge" (Bjerg 2011a; 247ff.).

Elever i tre generationer påkalder sig et righoldigt repertoire af subjektpositioner, som de identificerer sig med eller differentierer sig fra i deres erindringer om livet i skolen. I en sådan 'identitetsoptik' befolkes skoleerindringer af positioner, som er relativt genkendelige på tværs af tid og generationer (f.eks. Bjerg 201la; Kofoed 2005; Southgate 2003; Johansson 2000). De identitetsmarkører, som påkaldes i skoleerindringerne, er ikke alene genkendelige på tværs af tre generationer af elever. De giver også genlyd i feltet af feministiske og poststrukturalistiske undersøgelser af subjektivering i det levede skoleliv (f.eks. Bjer- 
rum Nielsen 2000; Cawood 2007; Davies og Gannon 2006; Juelskjær 2008; Staunæs 2004, 2009). Disse studier af køn og skoleliv udfolder, hvordan det at være og at blive elev er txt forbundet med at gøre køn langs mere eller mindre rigide konstruktioner af maskulinitet og femininitet i figurer af det passende og det upassende (Kofoed 2005a; Staunæs 2004; Søndergaard 1996, 2005).

Fokus i denne artikel er, hvordan livet i skolen også kan læses gennem analysestrategier med blik for affekt og intensitet for herigennem at illustrere, hvordan en analytisk 'identitetsoptik' kan suppleres med en 'intensitetsoptik'. Først præsenteres centrale begreber i Brian Massumis tænkning med henblik på at udfolde disse i en række af analytiske greb, der omsættes i et eksempel på en empirisk analyse af, hvordan maskulinitet gøres, men også fornemmes og føles i erindringer om livet i skolen.

Det primære sigte er at forfølge og bidrage til den igangværende udforskning af, hvordan analysestrategier udviklet i og med "den affektive vending" (Clough 2007; Bjerg \& Staunæs 2011; Kofoed \& Ringrose 2012; Puar 2012; Sedgwick 2003;) på en gang kan udfordre og supplere poststrukturalistisk feministisk forskning i subjektivering (f.eks. Butler 1990, 1997; Davies 2000, 2006; Staunæs \& Kofoed 2007; Søndergaard 2000, 2002) og intersektionalitet (Carbin \& Thornhill 2004; Juelskjær 2008; Lykke 2003; Phoenix 2006; Staunæs 2003; Staunæs \& Søndergaard 2006; Søndergaard 2005). Det skal dog understreges, at artiklens bidrag primært ligger i at udfolde affektorienterede analytiske greb på subjektiveringsprocesser gennem et specifikt analytisk eksempel. Derfor går artiklen ikke i dybden med de gennemgående teoretiske diskussioner, der udspringer af det analytiske møde mellem begreber om affekt og intensitet $\mathrm{i}$ forhold til subjektivering og intersektionalitet.

Artiklen bygger på et kapitel i afhandlingen "Skoling af lyst. Følelser og fornemmelser $i$ tre elevgenerationers erindringer om livet $i$ skolen 1950-2000” (Bjerg 2011a). ${ }^{1}$ Med inspiration fra kollektivt erindringsarbejde (Davies \& Gannon 2006; Haug 1999; Hutters \& Krøjer 2008) har jeg interviewet i alt 31 tidligere elever, der har gået i skole i henholdsvis 1950erne, 1970erne og 1990erne. Kollektivt erindringsarbejde er en metodisk praksis, der oprindeligt er udviklet af den tyske feminist Frigga Haug primært med et terapeutisk og frisættende sigte i forhold til at integrere kvindelige erfaringer og levet dagligliv med teorier om politisk økonomi (Haug 1999:15 ff.). Metoden er siden blevet videreudviklet i mere poststrukturalistisk retning med en ambition om at skabe viden om subjektiveringsprocesser gennem fremskrivelse af sansemættede erindringer om eksempelvis 'at blive skolepige' (Davies \& Gannon 2006). Metoden handler kort fortalt om at deltagerne gruppevise undersøger deres erfaringer om et givent tema, ofte knyttet til identitetsdannelsesprocesser, ved i flere omgange at fortælle og genfortælle eller eventuelt nedskrive deres erindringer i relation til et fælles tema med henblik på at fremkalde sanselige detaljer. Jeg kan ikke yde metoden retfærdighed her, ligesom jeg langt fra brugte metoden i sin fulde form i forbindelse med min afhandling, men metodens fokusering på at spørge til og fremkalde fornemmelser af konkrete situationer og erindringer, der udveksles i en gruppe, har vist sig meget anvendelig i forhold til at producere sanselige erindringer om det levede skoleliv (Bjerg 201la; 93 ff.; Bjerg \& Rosén Rasmussen 2008, 2012). Det valgte empiriske eksempel, der indgår i denne artikel, er en erindring om fodboldspil og slåskamp i skolegården. Erindringen vil blive brugt til en analytisk tematisering af subjektiv tilbliv-else i skolegården i intersektion med køn, race og alder. Samtidig indskriver jeg eksemplet i feltet af analyser af konstruktioner af hegemonisk maskulinitet, særligt i skolelivet. Min brug af begrebet hegemonisk maskulinitet trækker på begrebet, som 
den kritiske maskulinitetsforsker Robert Connell har udviklet med udgangspunkt i strukturalistisk informerede patriarkatsteorier om kønsmagtsordninger til at indramme eller betegne de kønspraksisser, som udgør og udfolder den patriarkalske overordning af mænd og underordning af kvinder (Connel 1995: 77). Samtidig ligger der også i Connells begreb, at det netop er et dynamisk og processuelt begreb, idet der i forskellige kontekster kan være tale om forskellige hegemoniske praksisser og maskuliniteter (Connel og Messerschmidt 2005), som konstrueres og tager farve $i$ intersektioner med andre sociale kategorier (Lykke 2008: 120 ff; Præstmand Hansen 2009). Jeff Hearn har påpeget de analytiske problemer, som begrebets brug kan medføre i forhold til at indkredse, hvad begrebet dækker over (Hearn 2004). I sin kritik kan Hearn måske siges at trække begrebet eller forståelsen af begrebet i samme retning som f.eks. diskurspsykologiske studier af subjektivering, hvor begrebet 'sættes på arbejde' i empiriske studier af subjektivering og til-blivelse, med fokus på at vise lokale og variable maskulinitetskonstruktioner i studier af 'levet liv' - eller det diskurspsykologerne Wetherell og Edley kalder 'the nitty gritty' i maskulinitetskonstruktioner (Wetherell \& Edley 1999). Min brug af begrebet ligger i forlængelse dels af poststrukturalistiske teoretiseringer af subjektivering og intersektionalitet, dels af de empiriske analyser af kønskonstruktioner i skolelivet, som mit studie indskriver sig i, hvor begrebet hegemonisk maskulinitet også optræder (Kofoed 2003, 2005a; Southgate 2003). Disse analyser viser empirisk, hvordan visser maskulinitets konstruktioner, der indtager en hegemonisk eller hegemonisererende plads i bestemmelsen af passsende og upassende måder at gøre og dermed blive til som den sociale kategori 'dreng i skolerummet'. Det hegemoniske handler altså ikke alene om en kønsmagtsordning, men også om en socio-kulturel dominans af visse maskulinitetskonstruktio- ner. Det skal dog understreges, at analysens primære sigte hverken er at udfolde en empirisk analyse af maskulinitetskonstruktioner og -gørelser i det empiriske materiale som helhed, ej heller at bidrage til teoretiseringer over begrebet. Analysen af hegemonisk maskulinitet bruges fortrinsvis som omdrejningspunkt til at anskueliggøre, hvordan læs- ninger efter affekt og intensitet på en gang lægger sig i slipstrømmen af poststruktura-listiske og feministiske analyser af subjektivering og intersektionalitet, specificeret i sociale konstruktioner af maskulinitet, men samtidig, hvordan et 'intensitetsperspektiv' kan bruges til at supplere og krydse disse analyser.

\section{EN VENDING MOD AFFEKT}

I sin introduktion til "den affektive vending” skriver Patricia Clough: "[...] affect refers generally to bodily capacities to affect and be affected or the augmentation or diminution of a body's capacity to act, to engage, and to connect, such that auto affection is linked to the self-feeling of being alive - that is, aliveness or vitality." (Clough 2007: 2). Clough indskriver affektbegrebet i en tradition, der trækker på filosofferne Gilles Deleuze, Felíx Guattari, Henri Bergson og ikke mindst Baruch Spinoza. Grundfiguren i Massumis affektbegreb er i vid udstrækning taget fra Spinoza og forstås som "potentialet" eller "kraften til at affekte og blive affektet" i forbindelser og relationer (Massumi 2002: 15). I relation til citatet kan yderligere to forhold tilskrives affektbegrebet; affekt knyttes an til skift i kapacitet og til fornemmelser af vitalitet; det vitalistiske aspekt i mindre grad hos Massumi, mens kapacitetsdimensionen står centralt. Massumis erkendelsesinteresse er at udvikle begreber, der ikke bare gør det muligt at tænke og analysere affekt, men også bevægelse og forandring. Massumi tager afsæt i en ikke synderlig specificeret kritik af poststrukturalistiske fokuseringer på tilblivelse indenfor et net ("grid") af relativt fas- 
te subjektpositioner og er optaget af forandring forstået som epokegørende brud eller subversive handlinger (Massumi 2002: 2 ff.). Heroverfor udfolder han sin egen tænkning om forandring forstået som “[...] the slightness of ongoing qualitative change" (Massumi 2002: 1). Forandring forstås som 'den mindste' kvalitative forandring eller forskydning. Dette kan forstås som eksempelvis et pludseligt stemningsskifte, der forandrer en hel situation, uden at der nødvendigivs er 'sket' eller ændret noget: "Qualitative difference: immediately the issue is change" (ibid.: 1). Den kvalitative forskel eller erfaring forbindes endvidere netop til affekt og oplevelse af forøget eller formindsket kapacitet:

[...] a power to affect and be affected governs a transition, where a body passes from one state of capacitation to a diminished or augmented state of capacitation. This comes with the corollary that the transition is felt. [...] what is felt is the quality of the experience. (Massumi 2009: 1-2, min kursivering).

Affekt som 'kraften til at bevæge og blive bevæget' henviser ikke til en personlig folelse, men til kropslig kapacitet, der sætter sig i en kvalitativ erfaring af indskrænket eller udfoldet kapacitet eller dueliggørelse. Affekt markerer således en overgang mellem en udvidelse eller en begrænsning i kroppens kapaciteter. Når jeg taler om såvel et intensitets- og et affektperspektiv skyldes det, at affekt og intensitet er næsten overlappende begreber hos Massumi. Dog mener jeg, at affekt i højere grad relateres til kvalitative skift - f.eks. hvor en ændring i et tonefald pludselig ændrer stemningen eller en situations 'affektive tonalitet'. Intensitet, derimod, registreres kvantitativt, f.eks. gennem faldende eller stigende intensitet $i$ en bestemt situation:

Intensity is incipience, incipient action and expression. Intensity is not only incipience, it is also the beginning of a selection: the incipi- ence of mutually exclusive pathways of action and expression, all but one of which will be inhibited, prevented from actualizing themselves completely (Massumi 2002: 30).

Stigende intensitet er ensbetydende med, at noget er 'i sin vorden' ikke blot tilblivelse, men et skridt 'før': Der er tale om et kim, men endnu er det ikke klart, hvad det er kimen til. Intensitet er begyndelsen til udvælgelse af en handling, frem for andre handlinger eller af dueliggørelse eller manøvredygtighed i forhold til ét frem for noget andet. Heri ligger også koblingen til en forståelse af affekt og videre til Deleuzes begreb om det virtuelle:

The autonomy of affect is its participation in the virtual. Its autonomy is its openness. Affect is autonomous to the degree to which it escapes confinement in the particular body whose vitality or potential for interaction, it is. Formed, qualified, situated perceptions and cognitions fulfilling functions of actual connection or blockage are the capture and closure of affect. Emotion is the most intense (most contracted) expression of that capture - and of the fact that something always and again escaped (Massumi 2002: 35).

Affekt er autonom i den forstand, at affekt ikke kan reduceres eller omsættes til noget andet - f.eks. indfanges som mening eller følelse. Affekt kan i den forstand siges at være en åbning mod ubestemmelighed eller et potentiale, som altid er til stede eller immanent i det aktualiserede som virtualitet, men som kontinuerligt lukkes ned eller formes netop gennem aktualiseringer:

Deleuze desribes the virtual as an intense, torsional coalsescence of potential individuations. Pulling out a thread, or decompressing a differential strand of the fusional weave of experience, involves actualizing a virtuality (Massumi 2002: 190).

Som beskrevet ovenfor kan specifikke emo- 
tioner ses som lukninger af potentiale. Når affekt omsættes eller aktualiseres i en følelse, er det ensbetydende med, at det mulighedsrum, som momentvis åbnede sig i affekt, lukker sig om den enkelte realiserede eller aktualiserede mulighed. En bevægelse eller berørelse inddæmmes som vrede, sorg eller glæde. Men samtidig betyder bestemmelsen af følelsen, at ét er blevet aktualiseret frem for noget andet:

Emotion is qualified intensity, the conventinal, consensual point of insertion of intensity into semantically and semiotically formed professions, into narrativizable action-reaction circuits, into function and meaning. It is intensity owned and recognized (Massumi 2002: 28).

Emotion bestemmes som indfanget og fortolket affekt, og idet affekt lukkes ned i en følelse eller betydning, bliver følelsen også en markering af lukning af potentiale. Hermed er vi tilbage ved forholdet mellem forandring, fiksering og tilblivelse:

\section{Change is emergent relation, the becoming sen-} sible in empirical conditions of mixture, of a modulation of potential. Post-emergence, there is capture and containment. Rules are codified and applied. The intermixing of bodies, objects, and signs is standardized and regulated. Becoming becomes reviewable and writable: becoming becomes history (Massumi 2002: 77, min kursivering).

\section{AFFEKTIVE HÆNDELSER SOM ANALYTISKE GREB}

Spørgsmålet er så, hvordan disse mere eller mindre definerede og definerende begrebsliggørelser kan omsættes til analytiske greb i et kvalitativt, empirisk materiale. Her kan citatet om emotioner bruges til at tematisere, hvad det er, jeg foretager mig i den kommende analyse, der fokuserer på at følge affekt og intensitet. De erindringer, jeg kan bruge som afsæt for analysen, er jo net- op fortalt og måske også erindret i meningsskabende forløb, og i interviewsituationen sprogliggøres de (igen) og indfanges således netop som 'fortællelige' i relation til "funktion og betydning". I den forstand kan man sige, at jeg $i$ analysen af erindringerne bruger Massumis tænkning om affekt, intensitet, kvalitativ erfaring, forandring og tilblivelse som netop teoretiske forståelser eller, kunne man også sige, som ontologiske forståelser af forandring og tilblivelse gennem affekt og intensitet. Den affektfulde forbindelse mellem affekt, kvalitativ erfaring og dueliggørelse eller kapacitering ledes i affektperspektivet snarere gennem intensitet og krop end gennem identitet og subjekt. Affektperspektivet tilbyder således en begrebsliggørelse af de myriader af sansninger af åbninger og lukninger af kapacitet, som har sat sig spor i erindringerne, og som jeg empirisk blandt andet noterer som registreringer af muligog umuliggjorte lyster. Samtidig er disse registreringer en 'baguddiskontering' af affekt og intensitet $\mathrm{i}$ forhold til erindringerne. Jeg forudsætter så at sige, at der bag, før eller snarere $i$ enhver fortalt lyst og/eller følelse ligger en ufortalt eller ubestemmelig affekt og intensitet. Dette greb viderefører jeg også i forhold til at finde et startsted for analyse, hvor jeg også vrider eller måske snarere 'forstørrer' Massumis forståelse af 'event' eller, som jeg vil kalde det, 'en affektiv hændelse':

The separately recognizable, speakable identities of the objects and subjects involved in the unfolding event come into definition only retrospective. In the event, they are inseparable from the immediacy of the relation. Their coming-together precedes their definition. And it is their definition that culminates the event: only after it has run its course can the situation be fully contextualized, accurately determined to have been a particular case of a certain general class of happening (Massumi 2002: 31, min kursivering). 
Når erindringerne fortælles i en interviewsituation er det sprogligt og oftest som en bestemt fortælling, en særlig 'kategori af hændelser', som Massumi skriver ovenfor. Samtidig vil jeg i det nedenstående eksempel netop forsøge analytisk at 'rulle hændelsen tilbage' fra den klare, narrative forståelse af, hvad der skete, til registreringer af ubestemmelig, men markant, affekt og intensitet.

\section{FOD MØDER BOLD}

I en første læsning kan erindringen nedenfor siges at handle om fodbold, slåskamp og smerte, og i et analytisk perspektiv om subjektiv tilblivelse $\mathrm{i}$ intersektioner af elevhed, hvidhed og 'drenghed'. Det er Søren, der fortæller om en af sige talrige, dårlige erindringer fra sin skolegang i 1970erne. Han indleder med at fortælle om James, der gik en klasse under ham selv og var den eneste sorte elev på skolen:

“[T]il gengæld' var han særdeles sort [...] Han blev ikke hånet sådan, men der var sådan noget med ham. Han var anderledes. [...] der var noget ved ham der James, efter han var kommet, sådan i stemningen omkring ham" (Søren).

Præsentationen af James danner baggrund for erindringen om et frikvarter, hvor drengene fra Sørens klasse spillede fodbold med en tennisbold mellem nogle søjler i skolegården:

“[...] og så var der en, der lagde en ind og afleverede, som jeg missede, og så sparkede James til bolden, og det var ikke så godt. [...] jeg tror bare, han forsøgte at skyde den tilbage, men det var det, at han rørte ved den" (Søren).

Hændelsen var egentlig ikke usædvanlig i frikvarterernes stadige række af skubbende, asende og masende kroppe. Men denne gang var det anderledes:
"Fodboldkampen gik i stå, og så blev det sådan noget med, at det var mig, der skulle have haft bolden, og James havde sparket til den, og hvad jeg havde tænkt mig at stille op med det [fælles latter] [...]. Det blev ikke sagt direkte, gå over og bank ham, men det var lidt ligesom det, der lå i luften. Jeg kan huske, jeg tænkte, 'jeg tror bare, jeg lader som ingenting', og så ringede det jo op. Men det blev ligesom dagsordenen, og i næste frikvarter [banker i bordet], så var der nogle fra nogle andre klasser, der også havde hørt om det. Jeg kan huske, sidst på dagen var jeg simpelthen nødt til at slås med ham, fordi der stod nærmest hele skolen bagved mig, mens jeg stod og rørte James og gloede på ham, og han stod og gloede på mig. Og så ville man se blod. 52, 300, 400 [...] enormt mange børn. [...] Jeg kan huske, jeg simpelthen prøvede på at undgå det, og jo mere jeg prøvede at undgå det, jo værre blev det. Jeg var selvfølgelig nødt til at lange ham en på hatten, så han slog igen, og så sloges vi, og så kom gårdvagten, og så var det ligesom ude af verden. Men det var frygteligt" (Søren).

Ud af mødet mellem bolden og netop dén fod voksede en affektiv hændelse, som ikke bare ændrede boldens bane, men skruede op for intensiteten og indvarslede et nyt sæt af forbindelser i skolen som affektivt rum (Bjerg 201la, 2011b). Hændelsen markerer både en stigende intensitet og en ændret affektiv kvalitet i situationen. Selvom fodboldspillet fysisk set gik videre, xndrede spillet karakter, idet det blev genspillet i det, der i erindringen videregives og slutteligt fremstår som en stadigt stigende anspændthed.

Inden jeg udfolder hændelsen i et affektivt perspektiv, skal jeg dog først læse den ind i eksisterende analyser af subjektivering i skolelivet med særligt fokus på konstruktion af maskuliniteter i relation til elevkategorien (Kofoed 2003, 2005a; Southgate 2003). I dette forskningsfelt analyseres subjektiv tilblivelse gennem begreber om performativitet eller gørelser, der knyttes til 
indtagelse af eller balancering mellem et mere eller mindre fast repertoire af subjektpositioner og intersektende sociale kategorier. Med afsæt i denne forskning kan denne og andre erindringer fra mit empiriske materiale indskrives $\mathrm{i}$ det, jeg har kaldt et 'kort over kønnede kontinuiteter' (Bjerg 2011: 249 ff.), idet konstruktionen af det passende og upassende synes at løbe langs meget genkendelige akser for elever med henholdsvis mandligt og kvindeligt kropstegn (Søndergaard 1996). Ikke mindst koblingen mellem mandligt kropstegn og en fordring om at performe maskulinitet gennem duelighed til sport, til ballade og drilleri samt til at udholde smerte er træk, der kan genkendes på tværs af tid og rum:

Enduring masculine subject positions include the larrikin, the big boy as rescuer, the basher of new boys and the sporting hero. These subject positions represent a form of hegemonic masculinity that is 'heterosexual, ablebodied [and] independent' (Hearn 1996: 211). Hegemonic masculine ideals such as management of pain and emotion are also fundamental to these positions (Southgate 2003: 191).

Jette Kofoed retter i sin analyse af konstruktioner af elevhed i intersektion med køn og etnicitet også blikket mod fodboldspillet, eller rettere mod holddeling som et gentagende ritual, der sætter drengenes positioner i forhold til hinanden på måder, der kan forskydes, men som oftest bliver en gentagelse af, hvem der kan indtage hvilke positioner (Kofoed 2005a). Hvis man analytisk konfigurerer erindringen ovenfor som en affektiv hændelse, og dermed drejer blikket fra positionering til affekt, intensitet og kapacitering kan fodboldspillet dog også anskues som et "felt af potentiale" (Massumi 2002: 82), hvor kroppene aktualiseres som fødder, der løber sammen i fælles tilblivelse gennem lysten og kapaciteringen eller dueliggørelsen til at løbe, sparke, skrue, ramme, sigte, bremse, speede, score.
Dueliggørelsen af fødderne til at gøre netop dette er tæet forbundet med en maskulin mærkning, idet det er gennem den sociale kategorisering af kroppene som 'drenge i skolegården', at det netop bliver føddernes duelighed til fodboldspil (og ikke træskodans) som aktualiseres.

Men hvad er det ved denne hændelse, som făr intensiteten til at stige og ændre affektiv karakter? Det er ikke det, at bolden ikke rammes og derfor triller ud af banen. Det skete så tit, fortæller Søren. Det er dét, at den fod, der sparker til bolden ikke kun er markeret med køn og alder, men også med race, med den 'sorteste sorthed'. Der er kun et enkelt sæt fødder af denne slags. Til gengæld er den særlige farve så meget desto mere intensiverende for "den stemning, der var omkring ham" og for den hændelse, der vokser ud af, at 'fod rører bold'. Med fascinerende hurtighed sker et skift, ikke bare i selve situationen, hvor spillet stopper, men i kompositionen af de kropsdele, der forbindes i affekt. Den raciale markering får effekt gennem en støt stigende og spredende intensitet, der gennembrød den sædvanlige, tidsmæssige adskillelse i frikvarter-lektion-frikvarter. Dagen igennem steg presset, idet flere og flere kroppe blev mærket af stemningen - og af hvidhed. En markering, hvor kroppenes kapacitet til slut blev kanaliseret ind i én eneste tilsyneladende uimodståelig bevægelse, der aktiverede hånden til det endelige slag. Væk var fødderne, væk var Søren, væk var i nogen grad - drengene og pigerne, idet andre identitetsmæssige kategorier ser ud til at være blevet overskygget af den raciale markering. Frem voksede en samling af hvide kroppe, hvis mærkbare hånd falder i slag for at markere deres eksklusivitet. I slaget adskilles hånden markant fra alle andre kapaciteter - at ae, at tegne, at skabe, at vinke, at stryge - og bliver kun til i sin duelighed til at slå. Intensiteten så stærk, at handlingsrummet indsnævres totalt: "Jeg blev nødt til...”. Den kvalitative erfaring, der har sat sig spor i denne erindring, kan siges at 
være erfaringen af en intersektende markering af hvidhed og drenghed af en meget ekskluderende karakter.

I denne markering afskæres andre mulige forbindelseslinjer mellem kropsdele og kapacitet - som for eksempel de forbindelseslinjer, der før løb gennem de fodboldspillende fødder, der markerede maskulint mærkede kroppe aktualiseret i 'lysten til fodbold'. En lyst, der kom til udtryk, indtil det moment, hvor bolden indrullerede en 'forkert' fod i spillet. Momentet kunne have udmundet i en hændelse, hvor markeringen i hvidhed og sorteste sorthed var blevet opløst. Hvor føddernes duelighed i fodboldspillet kunne have 'de-aktualiseret' den sorte farve og lavere alder til fordel for en markering af 'sammehed' i form af sammenløb af kategorier og markeringer i den delte lyst til boldspil. Men i hændelsen 'fod-rører-bold' skifter intensiteten og den affektive kvalitet $\mathrm{i}$ ansamlingen af pustende, masende og sparkende fødder, og spillet flyttes til et nyt 'felt af potentiale.' (Massumi 2002: 81-2). I erindringen markerer dette begyndelsen på en affektiv hændelse udstrakt i tid, intensitet og affekt henover skoledagen. Erindringen giver en fornemmelse af, at så længe kroppene er i affekt, men inden hånden falder $\mathrm{i}$ slag, er der en åbning mod potentialitet, mod flere mulige aktualise-ringer. Men da slaget falder, lukkes dette potentiale, da den sort/hvide markering aktualiseres endnu en gang.

Lukningen af sprækken til det potentielle sker dog ikke uden et overskud af affekt (Massumi 2002: 35). I erindringen viser affekten sig i den kvalitative erfaring af den formindskede duelighed, hvormed hånden falder i slag. Der er kun ét hånden kan gøre. Det potentielle aktualiseres i et meget snævert mulighedsrum. Samtidig fornemmes (u)dueliggørelsen af hånden gennem en kvalitativ erfaring. I erindringen narrativiserer og emotionaliserer Søren den kvalitative erfaring som en fornemmelse af forkerthed i at slå og lettelse over, at den hånd, der slår igen, rammer med samme kraft: "Heldigvis var James lige så stærk som mig" (Søren).

HVAD SKETE OG HVAD HÆNDTE: FORANDRING I ET AFFEKTIV PERSPEKTIV

I en analyse af kontinuitet og forandring $\mathrm{i}$ tilblivelsesprocesser kan man spørge, hvad der skete? Idet 'hvid dreng slår sort dreng' kan man iagttage, hvordan den sociale kategori dreng sætter sig igennem i skolelivet, idet det at slå markerer tilblivelse som passende maskulint kropsmærket, men i intersektion med racekategorien, der samtidig ser ud til at gennemskære eller markere 'sammehed' eller enshed frem for forskellighed mellem maskulint og feminimt kropsmærkede elever forenede i hvidhed. Vi kan dog også spørge, hvad der hændte i et affektivt perspektiv. Ved at følge situationen som en affektiv hændelse bliver det muligt at se, hvordan det maskuline slag og kategoriseringen af hvid versus sort ikke 'bare' skete. Sørens erindring handler også om, hvordan maskulinitet honder i en proces, der foregår gennem afskæringer og lukninger af potentialitet. Og det bliver muligt at iagttage, hvordan hændelsen ikke alene producerede sammehed eller identitet i det maskuline fællesskab, men at det at 'gøre' hegemonisk maskulinitet ses her knyttet til en blandet fornemmelse af forkerthed og lettelse.

På et niveau kan hændelsen således plottes direkte ind på kortet over kontinuiteter som en fortsættelse af holddelingens rituelle gørelse af maskulinitet, hvor de maskuline kroppe mærkes i deres kropslige kapabilitet til at spille fodbold, slås og udholde smerte i grænsevogtningen af intersektioner mellem køn, race og alder. Og der er tale om en hændelse, hvis effekt er fikserende frem for forskydende:

Chances are, when all is said and done, that the subjects and objects involved will be largely what they were in previous definitions. Largely the same but with some difference if only by virtue of their having come to be 
themselves again. They will be at least as different as last is from next (Massumi 2002: $32)$.

I et forandringsperspektiv er det analytiske tilbud i intensitetsperspektivet en begrebsliggørelse af 'forskellen' produceret i holddelingens, fodboldkampens, slåskampens igen og igen. Det er et analytisk perspektiv, der accentuerer kontingens forstået som det potentielles nærvær. Selv i dette tilfælde, hvor hegemonisk maskulinitet konstrueres $i$ en passende og gentagende formation, er der tale om en handling i affekt, hvorigennem det potentielle lader sig mærke uden at lade sig se. Er det Søren, der har en fornemmelse af, at dette er forkert, og at han må stritte imod? Eller er det fornemmelsen eller affekten, der har ham og hvirvler hans krop rundt $\mathrm{i}$ den kollektive bevægelse, der momentant forener visse kroppe på tværs af kønnede markeringer? En intens bevægelse, som til sidst skærer det meste af kroppens kapacitet af $i$ håndens dueliggørelse til at slå, udholde smerte - og påskønne en vis retfærdighed $i$, at smerten er ligeligt fordelt. Søren kan ikke se nogen anden udvej, for den er simpelthen ikkeeksisterende i den aktualisering af måder at gøre 'passende dreng', som blev praktiseret på hans skole. Men det betyder ikke, at han ikke kan morke det potentielle gennem affekt. Effekten i 'at blive sig selv igen' er ikke erfaringen af, at 'jeg kunne være blevet et andet selv', men af intensiteten i ikke at kunne blive til som andet end hånden, der slår.

Her tilbyder perspektivet en begrebsliggørelse af tilblivelse i affekt, intensitet og potentialitet. Affekt kan siges at markere den åbning, hvor det virtuelle lader sig mærke, hvor det potentielle siver ind og arresterer eller afbryder aktualiseringen. Analytisk kan man se den kvalitative erfaring af at indtage subjektpositionen som en markering af afstand til positionen $i$ en affektiv registrering af de-kapaciteringen forstået som indskrænkelse af kapacitet, samt af at det kunne have været anderledes - ikke som en refleksion, men som en sansning. I den aktuelle analyse gores der ikke bare hegemonisk maskulinitet $\mathrm{i}$ intersektion med hvidhed; det morkes også i form af en negativ, kvalitativ erfaring af kroppens dekapacitering.

\section{LYSTER PÅ TVÆRS}

Den intensitetsorienterede analyse ovenfor kan lægges ind som et supplement til en 'identitetsorienteret' analysestrategi. For at vise hvordan en læsning efter intensitet også kan bruges til at udfordre en identitetsorienteret læsning, skal jeg inddrage en anden af Sørens erindringer. Denne handler netop om at forfølge en lyst, der gik på tværs af de gørelser, der knyttede sig til det at gøre 'passende dreng' i skolelivet:

"Vi havde én lærer i historie, geografi og biologi, som virkelig gik til den med entusiasme. Og det kan jeg huske, det syntes jeg var skidesjovt. Det kunne jeg faktisk rigtig godt lide i mange år, og de andre drillede mig lidt, fordi jeg inviterede hende ind på mit fritidshjem, fordi jeg sammen med en sydamerikaner havde bygget Machu Picchu i papmache. Og de andre syntes, jeg var langt ude. [...] Det var sådan lidt fedterøvsagtigt at invitere læreren ind på fritidshjemmet for at se, hvad man havde bygget sammen med en eller anden tosse fra et andet land [latter]" (Søren).

Erindringen formidler en empirisk identificerbar lyst knyttet til at skabe og bygge en omfangsrig papmache model af et inkatempel i Peru. I et analytisk perspektiv kan man sige, at intensiteten i lærerens entusiasme så ud til at være så smittende, at den ikke bare satte sig i lyst og motivation i skolerummet, men også fulgte Søren på fritidshjemmet. Her delte han lyst med en anden krop, som han $\mathrm{i}$ erindringen ikke markerer ved køn, men ved nationalitet. Men hvor racekategorien i historien om James blev indsat som en forskelskategori, synes kategorien 'ud- 
lænding' i ovenstående erindring at blive gennembrudt og om ikke aflyst, så mindre betydningsfuld, idet de to kroppe forenes i fælles lyst og evne eller dueliggørelse til at skabe og producere. Intensitet og affekt $\mathrm{i}$ form af energi og lyst aktualiserer her en relation, hvor registreringen af forskel gennembrydes af en frlles (flugt)linje, der kanaliserer intensitet ind i kapacitet til at skabe frem for at slå. Erindringen rummer ikke umiddelbart forklaringen på, hvordan lysten får frit løb, men den er knyttet til fritidshjemmet, der muligvis har praktiseret en anden 'intensitetspolitik' end det, der i Sørens erindringer fremstår som skolerummets meget rigide kønsordning af lyst og tilblivelse. I hvert fald bliver lysten så bevægelig og bevægende, at den trænger frem til læreren, og bevæger hende hen på fritidshjemmet for at tage del i den delte lyst. Lysten overskrider den rigide opdeling $i$ at gide eller ikke gide, være engageret/ikkeengageret, der i skolelivet fremstår som en markering af at være med eller ikke med på holdet af 'passende drenge'. I denne erindring ser lyst - læst som affekt og intensitet - ud til at være $\mathrm{i}$ stand til momentvis at gennemkrydse kategorier og inddæmninger af race eller nationalitet; af skole og fritid; af lærer og elev; af at være med eller ikke med på drengeholdet. Den affekt, der i den første erindring havde en intensitet, der gjorde slaget uimodståeligt, har her ændret retning og karakter. Affekt kobles på tilblivelse ved at gennembryde de kategoriseringer, som før blev indstiftet i affekt.

\section{AFFEKTOPTIK PÅ TILBUD}

Ovenfor plæderer jeg for, at et affekt- eller intensitetsperspektiv tilbyder en række analytiske finjusteringer i analyser af subjektivering og intersektionalitet, specificeret $i$ analysen af intersektioner mellem hegemonisk maskulinitet og race. Argumentationen for intensitetsperspektivets mulige bidrag skal findes i udfoldelsen af det analytiske tilbud snarere end i en teoretisk argumentation, der udfolder den række af teoretiske snitflader, som intensitetsperspektivet åbner for $\mathrm{i}$ forhold til begreber om subjektivering, intersektionalitet, forandring og subversion. Sigtet er, som Eve Sedgwick har udtrykt det, at åbne poststrukturalistiske analyser af subjektivering for andre former for mening end diskursive konstruktioner (Sedgwick 2003: 6). Dette knytter an til det i øvrigt meget varierede felt af kropsmaterialistisk kønsteori, som Nina Lykke karakteriserer gennem begrebet postkonstruktionister: “[...] for så vidt som "post"-præfikset forstås som betegnelse for noget, der både “overskrider" og “inkluderer" (Lykke 2008; 81-82). Afslutningsvis skal jeg derfor opsummere de analytiske greb, som affektoptikken tilbyder, og som kan siges at både overskride men også at kunne inkluderes i analyser af subjektivering.

I et affekt- eller intensitetsperspektiv begrebsliggøres tilblivelsesprocesser ikke primært eller alene som performative gørelser og indtagelse af subjektpositioner i krydsninger af sociale kategorier. Tilblivelsesprocesser begrebsliggøres som bevægelser i og af affekt, der udgør, motiverer og intensiverer gørelserne (Sedgwick 2003: 17). Dette knytter an til den anden analytiske tilføjelse, hvor de kvalitative erfaringer af tilblivelsesprocesser tilbyder en affektiv toning af subjektiveringsanalyser, hvor affekter ' $i$ sig selv' tilskrives analytisk betydning. Ovenfor kommer dette til udtryk i analysen af, hvordan Søren gør hvid-dreng-slår-sort-dreng, men også hvordan den kvalitative erfaring af denne gøren - som knyttet til ubehag og lettelse - lægger sig ind $\mathrm{i}$ analysen af tilblivelse (Marrati 2006: 322). Det tredje analytiske tilbud handler om forholdet mellem tilblivelse og bevægelse forstået som forholdet mellem forandring og kontinuitet eller gentagelighed. Her mener jeg, at Massumis begrebsliggørelser af bevægelse og forandring - også i gennemsætningen af sammeheden og identiteten med sig selv - kan være en frugtbar måde at begrebssætte det forhold, at kontinuiteten, der umiddelbart 
tager sig ud som (s)tilstand, kun kommer i stand gennem stadige processer, relationer og bevægelser, der, selv når de vender tilbage til 'sig selv', tilfører en fornemmelse af at blive til igen og igen, samt en affektiv toning, der kan angive en nuanceforskel eller en total 'makeover'. Her ligger den sidste pointe i forbindelse mellem affekt og forandring, idet affekt er den måde, hvorpå det virtuelle lade sig mærke og dermed åbner for nye potentielle aktualiseringer (Puar 2012; 61). I Jasbir Puars diskussion af intersektionalitet i relation til assemblage teori, problematiserer Puar, hvordan Massumi forudsætter en differentiering mellem køn (sex/gender) og dermed forudsætter og taler ind i nettet af eksisterende subjektpositioner som noget relativt stabilt, på trods af hans favorisering af bevægelse og forandring. I et analytisk perspektiv kommer det, jeg vil kalde en 'ontologisering' af bevægelse til syne som det manglende sted, hvorfra man analytisk kan bestemme, hvornår der er tale om bevægelse hen imod sammehed, og hvornår der analytisk kan 'dømmes' forandring. I analysen har jeg netop indlejret affektanalysen af hegemonisk maskulinitet i en allerede eksisterende 'kortlægning' af nettet af mulige subjektpositioner for at få en analytisk ramme, der gør det muligt at pege på bevægelighed, genindsættelse eller gennemkrydsning af kategorier, positioner og identiteter. Det fører for vidt her at diskutere mulige teoretiske og analytiske veje ud af denne problematik. Dog kan man pege på, hvordan affektoptikken i en mere Deleuze-informeret og vitalitstisk læsning kan siges at dreje spørgsmålet og den identitetspolitiske interesse for forandring og subversion, der ligger i analyser af subjektivering og intersektionalitet (se f.eks. Kofoed og Staunæs 2007) som en intensitetspolitisk eller 'kapaciteringsetisk' problematik, idet skellet bliver lagt ved spørgsmålet om kapacitering eller de-kapacitering i højere grad end ved forandring og subversion:

While the capacity of a body to be affected remains more or less constant, whatever the relative proportion of active and passive affections may be, the passive affects, the sad passions, distance and detach the body from its power of being; the active affects, joy or even beatitude, on the contrary, bring it closer to its power of existing (Marrati 2006: 317).

\section{Noter}

1. Projektet var finansieret af FKK og var tilknyttet forskningsprojektet 'Skolen for Livet' under ledelse af Ning de Coninck-Smidth.

\section{LITTERATUR}

- Bjerg, H. (201 la): Skoling af lyst. Fantasier og fornemmelser $i$ tre elevgenerationers erindringer om livet i skolen 1950-2000. Ph.d.-afhandling (upubliceret), Institut for Læring. Danmarks Pædagogiske Universitet, København.

- Bjerg, H. (2011b): Skolen virker! Tre analytiske perspektiver på skoling af lyst i et historisk perspektiv, i: Nordiske Udkast 2011/39 (1\&2): 108-121.

- Bjerg, H. \& Rosén Rasmussen, L. (2008): Enacting Subjectivities in Educational History. Methodological reflections on the unse of qualitative interview for history writing, i: Pedagogica Historica. International Journal of the History of Education XLIV (6): 721-731.

- Bjerg, H. \& Rosén Rasmussen, L. (2012): Prompting techniques - researching subjectivities in educational history, i: Oral History Journal. Journal of the Oral History Society 40 (1): 89-99. - Bjerg, H. \& Staunæs, D. (2011): Appreciative Leadership and Shame. Bringing together Govermentality Studies and the Affective Turn. Ephemera, theory and politics in organisations. Lokaliseret (d. 11/11/2013) på:

http://www.ephemerajournal.org/sites/default/f iles/11-2bjergstaunaes_0.pdf

- Butler, J. (1990): Gender Trouble: Feminism and the Subversion of Identity. Routledge, New York \& London.

- Butler, J. (1993): Bodies That Matter. Routledge, New York \& London.

- Butler, J. (1997a): The Psychic Life of Power, in: Theories in Subjection. Stanford University Press, Stanford, Californien.

. Carbin, M. \& S. Thornhill (2004): Intersektionalitet - ett oanvändbart begrepp? i: Kvinnoveteskaplig tidskrift 25(3): 111-114. 
. Cawood, S. H. (2007): Velkommen til pussyland. Ph.d. afhandling. Danmarks Pædagogiske Universitetsskole, København.

- Connel, R. W. (1995): Masculinities. Polity

Press, Cambridge.

. Connel, R. W. \& Messerschmidt, J. W. (2005):

Hegemonic Masculinity. Rethinking the Concept,

i: Gender \& Society 19(6): 829-859.

- Davies, B. (2000): A Body of Writing 1990-1999.

Alta Mira Press, Oxford.

- Davies, B. (2006): Subjectification: The relevance of Butler's analysis for education, i: British Journal of Sociology of Education 27(4): 425-438.

- Davies, B. \& Gannon, S. (eds.) (2006): Doing

Collective Biography: investigating the production of subjectivity. Open University Press, Berkshire.

- Haug F. et. al. (1999): Female Sexualization - A Collective Work of Memory. Verso, London \& New York.

- Hearn, J. (2004): From Hegemonic Masculinty to the Hegemony of Men, in: Feminist Theory Vol. 5(1): 49-72.

· Hutters, C. \& Krøjer, J. (2008): Kollektivet som korrektiv: Fortælleværksteder som kritik af neoliberalt selvarbejde, i: Tidsskrift for Arbejdsliv 10(1):

$72-88$.

- Johansson, U. (2000): Normalitet, kön och klass.

Liv och lärande $i$ svenska läroverk. Nykopia Tryck $\mathrm{AB}$, Stockholm.

- Juelskjær, M. (2008): Resisting and commiting to schooling: intersections of masculinity and academic position, i: International Journal of Qualitative Studies in Education 2008/1: 49-63.

- Kofoed, J. (2005a): Holddeling: Når der gøres maskulinitet og hvidhed, i: Kvinder, Køn \& Forskning 2005/3: 42-52.

- Kofoed, J. (2005b): Elevpli. Arbitrære punktummer i skoleliv og forskning, i: Nordiske udkast 33(2): 67-75.

- Kofoed, J. (2003): Elevpli - In- og eksklusionsprocesser blandt børn i skolen. Ph.d.-afhandling. Institut for Pædagogisk Psykologi. Danmarks Pædagogiske Universitet, København.

- Kofoed, J. \& Ringrose, J. (2012): Travelling and sticky affects: Exploring teens and sexualized cyberbullying through a Butlerian-Deleuzian-Guattarian lens, i: Discourse: Studies in the Cultural Politics of Education 33(1): 5-20.

- Kofoed, J. \& Staunæs, D. (eds.) (2007): Magtballader. 14 fortallinger om magt, modstand og menneskers tilblivelse. Danmarks Pædagogiske Universitetsforlag. København.

- Lykke, N. (2008): Konsforskning. En guide til feministisk teori, metodologi og skrift. Samfundslitteratur, Frederiksberg.
- Lykke, N. (2005): Nya perspektiv på intersektionalitet: problem och möjligheter, i: Kvinnoveteskaplig tidskrift 26 (273): 7-17

- Marrati, P. (2006): Time and Affects. Deleuze on Gender and Sexual Difference, i: Australian Feminist Studies, 21(51): 313-325.

- Massumi, B. (2002): Parables for The Virtual. Movement, Affect, Sensation. Duke University Press, Durham \& London.

. Massumi, B. \& McKim, J. (2009): "Of Microperception and Micropolitics". An Interview with Brian Massumi, 15 August 2008, in: Inflexions: $A$ Journal for Research-Creation 2009/3: 20.

- Phoenix, A. (2006): Interrogating Intersectionality: productive ways of theorizing multiple positioning, i: Kvinder, Køn \& Forskning. 2006/2-3: 21-31. København.

. Puar, J. K. (2012): "I would rather be a cyborg than a goddess". Becoming-Intersectional in Assemblage Theory, i: philoSOPHIA 2012: 49-66. - Præstmann Hansen, R. (2009): Autoboys.dk. En analyse af maskulinitets- og etnicitetskonstruktioner $i$ skolelivet på automekanikeruddannelsen. Ph.d. afhandling. Københavns Universitet, København.

- Sedgwick, E. K. (2003): Touching Feeling. Affect, Pedagogy, Performativity. Durham \& London, Duke University Press.

- Sedgwick, E. K. \& Frank, A. (eds.) (1995): Shame and its Sisters. A Silvan Tomkins Reader. Duke University Press, Durham \& London. - Southgate, E. (2003): Remembering School. Mapping Continuities in Power, Subjectivity, \& Emotion in Stories of School Life. Peter Lang, New York. . Staunæs, D. (2009): 'A very sick' (challenge of) leadership. Intersections of ethnic-racialised masculinities, affective economy and subtle forms of soft leadership, i: Åsberg, C. et al: Gender Delight. Linköping University Press, Linköping.

- Staunæs, D. (2004): Køn, etnicitet og skoleliv. Samfundslitteratur, Frederiksberg.

- Staunæs, D. (2003): Where Have All the Subjects Gone? Bringing Together the Concepts of Intersectionality and Subjectification, i: NORA, Nordic Journal of Women's Studies 11/3: 101-10.

- Staunæs, D. \& Søndergaard, D. M. (2006): Intersektionalitet - udsat for teoretisk justering, i: Kvinder, Kon \& Forskning 2006/2-3: 43-56. - Søndergaard, D. M. (1996): Tegnet på kroppen. Køn: Koder og Konstruktioner blandt Unge voksne $i$ Akademia. Museum Tusculanum, København. - Søndergaard, D. M. (2000): Subjektivering og desire: Begreber på empirisk arbejde i akademia, i: Psyke \& Logos 23(1): 38-64.

- Søndergaard, D. M. (2002): Poststructuralist 
approaches to empirical analysis, i: Qualitative Studies in Education 15(2): 187-204.

- Søndergaard, D. M. (2005): Making Sense of Gender, Age, Power and Disciplinary Position: Intersecting Discourses in the Academy, $\mathrm{i}$ : Feminism \& Psychology 15(2): 189-208.

. Wetherell, M \& Edley, E. (1999): Negotiating Hegemonic Masculinity: Imaginary Positions and Psycho-Discursive Practices, i: Feminism \& Psychology Vol. 9, No.3: 335-356.

\section{SUMMARY}

Hegemonic masculinity revisited. The analysis unfolds an analytical perspective on affect and intensity based on the conceptualisations of Brian Massumi. It is argued that the analytical conceptualisation of affect, intensity, capacitation and potential offers new analytical and critical perspectives to the analysis of subjectification and intersectionality. The argument is unfolded through an analytical example on the construction of hegemonic masculinity within the lived life of schooling.

Helle Bjerg, Lektor PhD

Professionshøjskolen UCC, Afdeling for Forskning, Udvikling og Internationalisering 